\title{
Recommendations for the use of opioids in Brazil: Part II. Use in children and the elderly*
}

\author{
Recomendações para uso de opioides no Brasil: Parte II. Uso em crianças e idosos \\ Durval Campos Kraychete ${ }^{1}$, José Tadeu Tesseroli de Siqueira² ${ }^{2}$ João Batista Santos Garcia ${ }^{3}$ and Specialists Group
}

${ }^{*}$ Received from the Brazilian Society for the Study of Pain, São Paulo, SP, Brazil.

\section{ABSTRACT}

BACKGROUND AND OBJECTIVES: Pain management in age extremes and in children still requires attention and paradigms review. There are several diseases or procedures inducing pain from the neonatal period to adolescence. In the elderly, there is higher prevalence of degenerative diseases which induce acute and chronic pain. This study aimed at discussing recommendations for the use of opioid in neonates, children and the elderly.

CONTENTS: This review has addressed the use of opioids in the neonatal period, in older children and in the elderly, their indications, drugs used, doses, risks, complications and recommendations.

CONCLUSION: The use of opioids in age extremes is still a challenge. However, ongoing education about the subject is needed, encouraging clinical trials and the development of evidence-based recommendations. The safe use of such agents in correct indication and proportion for pain relief decreases risks and should be the basis for good clinical practice.

Keywords: Children, Elderly, Opioids.

\section{RESUMO}

JUSTIFICATIVA E OBJETIVOS: O tratamento da dor nos extremos de idade e na criança ainda exige atenção e revisão de paradigmas. Inúmeras são as doenças ou procedimentos que provocam dor desde o período neonatal até a adolescência. Nos idosos, há maior prevalência de doenças degenerativas que cursam com dor aguda e crônica. O objetivo deste estudo foi discutir recomendaçóes para o emprego de opioides no neonato, na criança e no idoso.

CONTEÚDO: Nesta revisão foi abordado o emprego de opioides no período neonatal, em crianças maiores e nos idosos,

1. Federal University of Bahia, Salvador, BA, Brazil.

2. University of São Paulo, São Paulo, SP, Brazil.

3. Federal University of Maranhăo, Săo Luis, MA, Brazil.

Correspondence to:

Durval Campos Kraychete

Rua Rio de São Pedro, 327/401 - Bairro Graça

40150-350 Salvador, BA, Brasil.

E-mail: dkt@terra.com.br

(C) Sociedade Brasileira para o Estudo da Dor suas indicaçôes, fármacos usados, doses, riscos, complicaçôes e recomendaçóes.

CONCLUSÁO: O emprego de opioides em extremos de idade ainda é um desafio. No entanto, é necessária a educação continuada em torno do tema, estimulando a pesquisa clínica e a construção de recomendaçóes baseadas em evidências. $\mathrm{O}$ uso seguro desses agentes na indicação e proporção corretas para o alívio da dor diminui riscos e deve ser a base da boa conduta clínica.

Descritores: Criança, Idoso, Opioides.

\section{INTRODUCTION}

The correct and monitored use of opioids is still a challenge for health professionals. So, by initiative of a group of specialists, with institutional validation of the Brazilian Society for the Study of Pain (SBED), we decided for a publication, the major proposal of which is to present recommendations to guide health professionals in the use of opioids to control acute and chronic pain. Continuing with our work, this study will discuss the use of opioids in neonates, older children and the elderly, their indications, drugs used, doses, risks and complications. Recommendations presented here and in future publications in a sequenced manner, aim at starting the development of a practical guide for the adequate treatment of patients, disclosing available recommendations with regard to the use of opioids in different clinical situations, encouraging studies related to their safety and effectiveness, as well as at demystifying the inadequate association between addiction/dependence and the use of opioids.

\section{USE OF OPIOIDS IN CHILDREN}

Notwithstanding what was believed until the 1980's, pediatric patients of all age groups, even in extreme preterm levels, are able to feel pain ${ }^{1,2}$. So, inadequate analgesia may induce immediate or long term consequences ${ }^{3-5}$. In spite of this knowledge, almost $80 \%$ of children admitted to neonatal intensive care units are still undertreated ${ }^{6}$. This may be related to lack of understanding of the anatomy and physiology of painful transmission, of pain evaluation scales, of analgesics pharmacokinetics and pharmacodynamics, in addition to the insecurity to administer drugs to the neonatal population due to fear of adverse effects ${ }^{7}$. Also, most children with advanced cancer feel pain until their last days of life, emphasizing the need for adequate management of the symptom in pediatrics ${ }^{8-13}$. So, it is important to change the idea 
that opioids induce intolerable adverse effects of difficult clinical handling; or that they may shorten children's life expectation or that they are related to high abuse potential ${ }^{8,10,14-17}$.

\section{OPIOIDS FOR NEONATES}

Modern neonatal intensive care units have used opioids both to relieve acute pain caused by procedures (injections, intubation, etc.) and chronic pain (necrotizing enterocolitis) ${ }^{18}$.

\section{Morphine}

Morphine is the most widely used drug in patients of all ages, including neonates under mechanical ventilation $(\mathrm{MV})^{19}$. Morphine is metabolized by the liver into morphine-3-glicuronide (inactive) and morphine-6-glicuronide (active), both excreted by kidneys. In general, its half-life is longer and plasma clearance is decreased in neonates, being more pronounced among preterm babies. The binding of morphine to proteins is also decreased, allowing a larger proportion of drug free fraction to penetrate the brain, increasing the risk of respiratory depression. On the other hand, at two months of age half-life and plasma clearance values are equal to those of adults, so it is necessary to carefully titrate the agent to obtain desirable levels of analgesia without adverse effects ${ }^{20}$. Preterm neonates produce more metabolites (morphine-3-gicuronide) than older children, and for being antagonist metabolite, neonates may develop tolerance three or four days after starting treatment $\mathrm{t}^{21}$. It is also important to highlight that neonates with gestational age below 26 weeks, with long periods of fast or hemodynamic instability and who need prolonged ventilatory assistance are at risk of hypotension with the use of morphine ${ }^{22-25}$.

\section{Fentanyl}

Fentanyl is 50 to 100 times more potent than morphine and highly lipophilic, resulting in significant penetration in the central nervous system. Due to its potency, to the possibility of not changing hemodynamic stability and to its fast onset of action, it has been widely used in intensive care units for painful procedures, both in continuous infusion and in single dose. Care must be taken because after five or more days of fentanyl continuous infusion there may be tolerance or withdrawal syndrome. Neonates, for having decreased levels of acid glycoprotein $\alpha-1$, protein to which the opioid normally binds, have more fentanyl plasma free fraction ${ }^{7,20}$. Studies with neonates using intravenous fentanyl during MV have observed decreased pain scores, stress and heart rate, as compared to placebo, in addition to increased growth hormone levels ${ }^{26}$. Analgesia was similar to morphine, however with less adverse effects ${ }^{27}$. There has been however more need to increase ventilation and peak inspiratory pressure rates in the first 24 hours.

\section{OLDER CHILDREN AND OPIOIDS: INDICATIONS}

\section{Postoperative pain}

Morphine: is indicated for moderate to severe pain not responding to common analgesics, weak opioids or regional blocks. It may be administered by different routes and techniques such as: intravenous or subcutaneous in loading dose $\left(50-100 \mu \mathrm{g} \cdot \mathrm{kg}^{-1}\right)$;

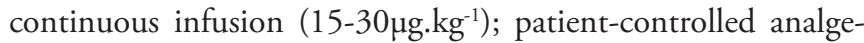
sia, with or without baseline infusion $\left(20 \mu \mathrm{g} \cdot \mathrm{kg}^{-1}\right.$ demand and $0-20 \mu \mathrm{g} \cdot \mathrm{kg}^{-1} \cdot \mathrm{h}^{-1}$ baseline infusion); neuroaxial $\left(30-50 \mu \mathrm{g} \cdot \mathrm{kg}^{-1}\right.$ in epidural space or in continuous infusion associated to local anesthetics) $)^{20,29}$.

Fentanyl: may be used by nasal $\left(2 \mu \mathrm{g} \cdot \mathrm{kg}^{-1}\right)$ or epidural $(1-2 \mu \mathrm{g}$. $\left.\mathrm{kg}^{-1}\right)$ route, by continuous intravenous infusion $\left(0,5 \mu \mathrm{g} \cdot \mathrm{kg}^{-1} \cdot \mathrm{h}^{-1}\right)$ and in loading dose $\left(0,5-1 \mu \mathrm{g} \cdot \mathrm{kg}^{-1}\right)^{20}$.

Tramadol and codeine: weak opioids with wide pharmacogenetic variability with regard to metabolization and equal or higher incidence of nausea and vomiting as compared to strong opioids ${ }^{20}$.

Methadone and nalbuphine for postoperative analgesia: little evidence of their use in children ${ }^{20}$.

\section{Persistent pain}

The World Health Organization (WHO) has recently published that the 3-steps analgesic ladder should be replaced by the 2-steps ladder, giving preference to low doses of strong opioids instead of using weak opioids such as codeine and tramadol, if non-opioid analgesics are insufficient to relieve pain. This because codeine has safety and efficacy problems related to genetic variability during biotranformation. Codeine is a prodrug which is converted to its active metabolite morphine by the enzyme CYP2D6. The efficacy of a prodrug depends on the amount of formed active metabolites. Variable expressions of enzymes involved in the biotransformation of prodrugs may lead to differences in conversion rates and plasma concentration of the active metabolite in an inter-individual and interethnical manner. In the fetus, CYP2D6 activity is absent or is less than $1 \%$ of adult values, increasing with birth. Estimates show that conversion value is not $25 \%$ of adult values in children below five years of age. So the analgesic effect is low or absent in neonates and infants. The percentage of weak metabolizers may vary according to ethnic groups from 1 to $30 \%$, resulting in inefficacy for a large number of people, including children. Conversely, individuals rapidly metabolizing codeine and in high proportion are at risk of opioid toxicity, given the high and uncontrolled conversion of codeine into morphine. There are no data about other intermediate opioids for pediatric use.

Tramadol is another opioid analgesic with favorable effects to control moderate pain. There is currently no available evidence of its efficacy and safety in children. Tramadol is not licensed for pediatric use in many countries. Further studies on tramadol and other intermediate opioids are needed. If disease-related pain intensity is considered as moderate or severe, it is necessary to administer a strong opioid. The risks of using strong and effective opioid analgesics overcome the uncertainty associated to codeine and tramadol response in children. However, if new studies are carried out using tramadol, codeine or alternative intermediate opioids, this risk-benefit ratio may be reconsidered. Remember that morphine is recommended as first line drug to treat 
moderate to severe pain in children with persistent pain. The choice for alternatives to morphine should be guided by safety, availability, cost and convenience considerations, including patient-related factors.

Morphine has relatively low cost and is available in more than one formulation. There is, however, the need for clinical trials comparing different opioids in terms of efficacy, adverse effects and viability for children with persistent pain. The development of safer formulations with adequate doses for these very young age groups should become a high priority. Opioid doses by different routes are shown in table 1 .

Table 1. Opioid doses by different routes according to age group

A. Initial doses for opioid-naive neonates:

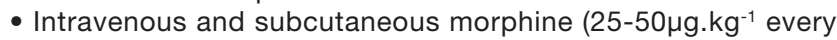

6h);

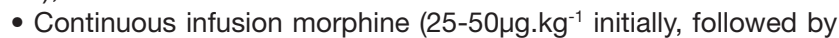
$\left.5-10 \mu \mathrm{g} \cdot \mathrm{kg}^{-1} \cdot \mathrm{h}^{-1}\right)$;

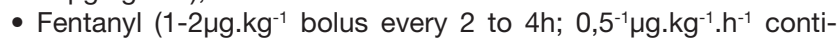
nuous infusion preceded by initial $1-2 \mu \mathrm{g} \cdot \mathrm{kg}^{-1}$ bolus).

B. Initial doses for opioid-naive children from one month to one year of age:

- Oral morphine immediate release (80-200 $\mu \mathrm{g} . \mathrm{kg}^{-1}$ every $\left.4 \mathrm{~h}\right)$;

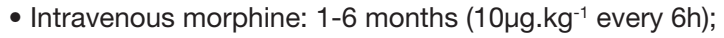

- Intravenous morphine: 6 to 12 months $\left(100 \mu \mathrm{g}_{\mathrm{kg}}{ }^{-1}\right.$ every $4 \mathrm{~h}$, maximum 2,5mg per dose);

- Continuous intravenous morphine infusion: 1 to 6 months $(50 \mu \mathrm{g}$.

$\mathrm{kg}^{-1}$, initially followed by $\left.10-30 \mu \mathrm{g} \cdot \mathrm{kg}^{-1} \cdot \mathrm{h}^{-1}\right)$;

- Continuous intravenous morphine infusion: 6 to 12 months (100-

$200 \mu \mathrm{g} \cdot \mathrm{kg}^{-1}$ initially followed by $20-30 \mu \mathrm{g} \cdot \mathrm{kg}^{-1} \cdot \mathrm{h}^{-1}$;

- Continuous subcutaneous morphine infusion: 1 to 3 months $\left(10 \mu \mathrm{g} \cdot \mathrm{kg}^{-1} \cdot \mathrm{h}^{-1}\right)$;

- Continuous subcutaneous morphine infusion: 3 to 12 months

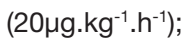

- Fentanyl $\left(1-2 \mu \mathrm{g} \cdot \mathrm{kg}^{-1}\right.$ every 2 to $4 \mathrm{~h}$ or $0,5^{-1} \mu \mathrm{g} \cdot \mathrm{kg}^{-1} \cdot \mathrm{h}^{-1}$ continuous infusion preceded by de dose 1 to $2 \mu \mathrm{g} . \mathrm{kg}^{-1}$ intravenous initial dose).

C. Initial doses for opioid-naive children from 1 to 12 years of age:

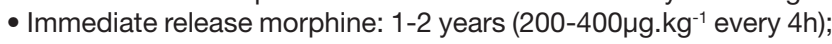

- Immediate release morphine: $2-12$ years $\left(200-500 \mu \mathrm{g} \cdot \mathrm{kg}^{-1} \cdot \mathrm{h}^{-1}\right.$ every

$4 \mathrm{~h}$, maximum of $5 \mathrm{mg}$ );

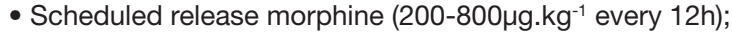

- Intravenous or subcutaneous morphine: $1-2$ years $\left(100 \mu \mathrm{g} \mathrm{kg}^{-1}\right.$

every $4 h$ );

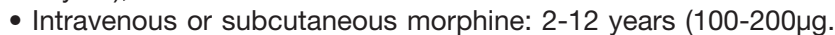

$\mathrm{kg}^{-1}$ every $4 \mathrm{~h}$, maximum $2,5 \mathrm{mg}$ );

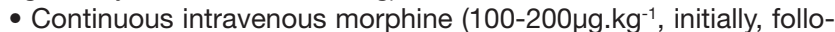
wed by $\left.20-30 \mu \mathrm{g} \cdot \mathrm{kg}^{-1} \cdot \mathrm{h}^{-1}\right)$;

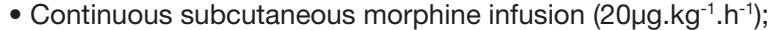

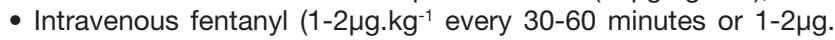

$\mathrm{kg}^{-1}$ initial dose followed by $1 \mu \mathrm{g} \cdot \mathrm{kg}^{-1} \cdot \mathrm{h}^{-1}$ continuous infusion);

- Oral, intravenous or subcutaneous methadone: $\left(100-200 \mu \mathrm{g} \cdot \mathrm{kg}^{-1}\right.$

every $4 \mathrm{~h}$ for first 2 to 3 doses and then, every 6 to $12 \mathrm{~h}$, maximum

$5 \mathrm{mg}$ per dose);

- Sustained release oxycodone (5mg every $12 \mathrm{~h}$ ).

Immediate release tablets or oral solutions may be used to titrate morphine doses for children. They are also indispensable to treat episodic pain or advanced disease. The availability of immediate release formulations has priority over scheduled release morphine. Remember that oral morphine is always an alternative when children are unable to swallow tablets. On the other hand, scheduled release tablets should be used to im- prove adherence to treatment and help the administration in prolonged intervals.

In the presence of inadequate analgesic effect with intolerable adverse effects, opioid rotation or changing administration route are strongly recommended. Optimal opioid titration for children is critical before considering changing to a different opioid. Change should only be considered when the administered drug was duly titrated but analgesic response was inadequate and adverse effects were intolerable. Safety while rotating opioids should be always evaluated, considering the overdose risk. Fentanyl, methadone and oxycodone formulations are considered alternatives to morphine for children with persistent pain. Attention should be given to age and different opioids dose conversion tables, which in general are empirical. Other factors to be considered when titrating and rotating opioids are: formulation bioavailability; interactions with other drugs; renal and liver clearance. The choice of alternative administration routes, when oral route is not available, should be based on clinical judgment, availability, viability and patients' preference.

Available studies on acute or postoperative pain do not provide conclusive evidences to orient recommendations by other routes. For chronic pain, there is the possibility of transdermal use and in special cases neuraxial administration. Intramuscular opioids should always be avoided in children due to induced pain. There is enough evidence to recommend a special opioid or administration route to treat spontaneous or incidental pain. It is necessary to choose the adequate treatment modality based on clinical judgment, availability, pharmacological issues and patient-related factors ${ }^{30}$.

\section{USE OF OPIOIDS IN THE ELDERLY}

Elderly people are less likely than younger people to complaint or accept opioids prescription for fearing the addiction effect, for associating opioids (especially morphine) to severe or terminal diseases, and for believing that, complaining of pain, they may need diagnostic investigation or hospitalization ${ }^{31}$. Also, some physicians are reluctant to prescribe opioids for this age group. It has however been described that the elderly have pain intensity comparable to that of young people and that the morphine dose necessary to decrease visual analog scale (VAS) to below 4 is not significantly affected by age ${ }^{32}$.

Os opioides são geralmente seguros para o idoso quando titulados cuidadosamente. Opioids are in general safe for the elderly when carefully titrated. They are also drugs inducing less organic toxicity as compared to anti-inflammatory drugs, and in studies using single dose of opioids there has been less cognitive impairment as compared to benzodiazepines ${ }^{33}$. In hospices treating patients with well-defined chronic pain, opioid abuse and addiction rates are very low ${ }^{34,35}$.

\section{Opioids risks for the elderly}

Overdose: several pharmacokinetic factors may determine that the elderly present increased risk to opioids overdose, as compared to younger patients. This is related to less binding to 
plasma protein, to lower ventricular ejection volume (decreases liver metabolism) and to higher sensitivity to psychoactive and respiratory effects of opioids $s^{36,37}$.

Excessive sedation: there is a high prevalence or elderly people under opioids associated to benzodiazepines and other psychotropic drugs ${ }^{38}$, increasing the risk of sedation.

\section{Recommendations for the use of opioids in the elderly ${ }^{39,40}$ :}

- Avoid using opioids in patients with cognitive deficit or who live alone, unless there is supervision for the adequate use of the drug;

- Start with the low dose (up to $50 \%$ of initial dose suggested to adults), slow titration and more spaced intervals between doses. Monitoring should be frequent and the use of benzodiazepines should be restricted to decrease risk of falls and cognitive impairment;

- Give preference to controlled release (CR) drugs. However, immediate release drugs may be used to control acute pain or as rescue drug;

- Consider three days to evaluate tolerance to opioid;

- Periodically monitor renal function or clinical changes;

- Recognize overdose signs, such as, slurred speech, emotional lability, ataxia and sleepiness during chat or activity;

- Prophylactically treat constipation when administering any opioid to the elderly;

- Remember that tramadol should be carefully started in patients under other psychotropic drugs, due to the higher potential of causing dizziness or serotoninergic crisis. Tramadol is contraindicated for patients with epilepsy and promotes less constipation than codeine.

\section{CONCLUSION}

The use of opioids in extreme ages is still a challenge. However, it is necessary ongoing education on the subject, encouraging clinical research and the development of evidence-based recommendations. So, the safe use of such agents in adequate indication and proportion for pain relief decreases risks and should be the basis for good clinical practice. This measure will surely decrease short and long term morbidity and promote patients' wellbeing.

\section{Authors of the Specialists group:}

Alexandre Annes Henriques

Anderson Arantes Silvestrini

Ângela Maria Sousa

Ariel de Freitas Q. Américo

Cláudio Fernandes Corrêa

Daniel Ciampi Andrade

Eduardo Grossmann

Erich Talamoni Fonoff

Gualter Lisboa Ramalho

Guilherme A. M. de Barros

Grace Haber

Inês T. V. e Melo

Irimar De Paula Posso
Janaina Vall

João Marcos Rizzo

João Valverde Filho

José Oswaldo de Oliveira Júnior

Judymara Lauzi Gozzani

Karine A. S. Leão Ferreira

Lia Rachel C. do Amaral Pelloso

Lin Tchia Yeng

Manoel Jacobsen Teixeira

Mario Luiz Giublin

Maria Teresa R. Jalbut Jacob

Miriam Seligman Menezes

Mirlane Guimarães Cardoso

Newton Monteiro de Barros

Onofre Alves Neto

Patrick Raymond Stump

Rioko Kimiko Sakata

Roberto T. de Castro Bettega

Rogério Teixeira

Sandra Caires Serrano

Sílvia Maria de Macedo Barbosa

Telma M. Zakka

Theodora Karnakis

Toshio Chiba

Waleska Sampaio

William Gêmio Teixeira

William Jacobsen Teixeira

\section{ACKNOWLEDGMENTS}

This recommendation was developed by the Brazilian Society for the Study of Pain with support of Janssen do Brazil.

\section{REFERENCES}

1. Anand KJ, Hickey PR. Pain and its effects in the human neonate and fetus. N Engl J Med. 1987;317(21):1321-9.

2. Fitzgerald M, Beggs $S$. The neurobiology of pain: developmental aspects. Neuroscientist. 2001;7(3):246-57.

3. Grunau RE, Holsti L, Haley DW, Oberlander T, Weinberg J, Solimano A, et al. Neonatal procedural pain exposure predicts lower cortisol and behavioral reactivity in preterm infants in the NICU. Pain. 2005;113(3):293-300.

4. Klein VC, Gaspardo CM, Martinez FE, Grunau RE, Linhares MB. Pain and distress reactivity and recovery as early predictors of temperament in toddlers born preterm. Early Hum Dev. 2009;85(9):569-76

5. Harrison D. Management and treatment of pain in infants. In: Mogil J, (editor). Pain 2010 An Update Review Refresher Course Syllabus. Seattle, IASP Press; 2010. 391-8p.

6. Carbajal R, Rousset A, Danan C, Coquery S, Nolent P, Ducrocq S, et al. Epidemiology and treatment of painful procedures in neonates in intensive care units. JAMA 2008;300(1):60-70.

7. Hall RW, Shbarou RM. Drugs of choice for sedation and analgesia in the neonatal ICU. Clin Perinatol. 2009;36(2):215-26.

8. Albano EA, Odom LF. Supportive care in pediatric oncology. Curr Opin Pediatr. 1993;5(1):131-7.

9. Contro N, Larson J, Scofield S, Sourkes B, Cohen H. Family perspectives on the quality of pediatric palliative care. Arch Pediatr Adolesc Med. 2002;156 (1):14-9.

10. Drake R, Frost J, Collins JJ. The symptoms of dying children. J Pain Symptom Manage. 2003;26(1):594-603.

11. Goldman A, Hewitt M, Collins GS, Childs M, Hain R. Symptoms in children/young people with progressive malignant disease: United Kingdom Children's Cancer Study Group/Paediatric Oncology Nurses Forum survey. United Kingdom Children's Cancer Study Group/Paediatric Oncology Nurses' Forum Palliative Care Working Group. Pediatrics. 2006;117(6):e1179-86. 
12. Jalmsell L, Kreicbergs U, Onelöv E, Steineck G, Henter JI. Symptoms affecting children with malignancies during the last month of life: a nationwide follow-up. Pediatrics. 2006;117(4):1314-20.

13. Wolfe J, Grier HE, Klar N, Levin SB, Ellenbogen JM, Salem-Schatz S, et al. Symptoms and suffering at the end of life in children with cancer. N Engl J Med. 2000;342(5):326-33

14. Brown RE Jr, Schmitz ML, Andelman PD. The treatment of pain in children. J Ark Med Soc. 1993;90(3):112-3.

15. Mack JW, Hilden JM, Watterson J, Moore C, Turner B, Grier HE, et al. Parent and physician perspectives on quality of care at the end of life in children with cancer. J Clin Oncol. 2005;23(36):9155-61.

16. Ellis JA, McCarthy P, Hershon L, Horlin R, Rattray M, Tierney S. Pain practices: a cross-Canada survey of pediatric oncology centers. J Pediatr Oncol Nurs. 2003;20(1):26-35.

17. Hilden JM, Emanuel EJ, Fairclough DL, Link MP, Foley KM, Clarridge BC, et al. Attitudes and practices among pediatric oncologists regarding end-of-life care: results of the 1998 American Society of Clinical Oncology survey. J Clin Oncol, 2001;19(1):205-12

18. Bellù R, de Waal KA, Zanini R. Opioids for neonates receiving mechanical ventilation. [update of Cochrane Database Syst Rev. 2005;(1):CD004212. Cochrane Database Syst Rev 2008;(1):CD004212.

19. Hall RW, Boyle E, Young T. Do ventilated neonates require pain management? Semin Perinatol. 2007;31(5):289-97.

20. Kraemer FW, Rose JB. Pharmacologic management of acute pediatric pain. Anesthesiol Clin. 2009;27(2):241-68.

21. Anand KJ. Pharmacological approaches to the management of pain in the neonatal intensive care unit. J Perinatol. 2007;27(Suppl 1):S4-S11.

22. Hall RW, Kronsberg SS, Barton BA, Kaiser JR, Anand KJ. Morphine, hypotension, and adverse outcomes in preterm neonates: who's to blame? NEOPAIN Trial Investigators Group. Pediatrics. 2005;115(5):1351-9.

23. Simons SH, van Dijk M, van Lingen RA, Roofthooft D, Duivenvoorden HJ, Jongeneel N, et al. Routine morphine infusion in preterm newborns who received ventilatory support: a randomized controlled trial. JAMA. 2003;290(18):2419-27.

24. Anand KJ, Hall RW, Desai N, Shephard B, Bergqvist LL, Young TE, et al. Effects of morphine analgesia in ventilated preterm neonates: primary outcomes from the NEOPAIN randomised trial. Lancet. 2004;363(9422):1673-82.

25. Kart T, Christup LL, Rasmussen M. Recommended use of morphine in neonates, infants and children based on a literature review: Part 2--Clinical use. Paediatr Anaesth. 1997;7(2):93-101.
26. Guinsburg R, Kopelman BI, Anand KJ, de Almeida MF, Peres Cde A, Miyoshi MH Physiological, hormonal, and behavioral responses to a single fentanyl dose in intubated and ventilated preterm neonates. J Pediatr. 1998;132(6):954-9.

27. Saarenmaa E, Huttunen P, Leppäluoto J, Meretoja O, Fellman V. Advantages of fentanyl over morphine in analgesia for ventilated newborn infants after birth: a randomized trial. J Pediatr. 1999;134(2):144-50.

28. Orsini AJ, Leef KH, Costarino A, Dettorre MD, Stefano JL. Routine use of fentany infusions for pain and stress reduction in infants with respiratory distress syndrome. J Pediatr. 1996;129(1):140-5.

29. Morton NS. Specific plans for pain prevention and control. In: Morton NS, (editor). Acute Paediatric Pain Management A Practical Guide. London: WB Saunders; 1998. 225-44p.

30. WHO Guidelines on the Pharmacological Treatment of Persisting Pain in Children with Medical Illnesses. Geneva: World Health Organization; 2012.

31. Robinson CL. Relieving pain in the elderly. Health Prog. 2007;88(1):48-53.

32. Wilder-Smith OH. Opioid use in the elderly. Eur J Pain. 2005;9(2):137-40.

33. O'Neill WM, Hanks GW, White L, Simpson P, Wesnes K. The cognitive and psychomotor effects of opioid analgesics. I. A randomized controlled trial of single doses of dextropropoxyphene, lorazepam and placebo in healthy subjects. Eur J Clin Pharmacol. 1995;48(6):447-53.

34. Ytterberg SR, Mahowald ML, Woods SR. Codeine and oxycodone use in patients with chronic rheumatic disease pain. Arthritis Rheum. 1998;41(9):1603-12.

35. Mahowald ML, Singh JA, Majeski P. Opioid use by patients in an orthopedics spine clinic. Arthritis Rheum. 2005;52(1):312-21.

36. Freye E, Levy JV. Use of opioids in the elderly -- pharmacokinetic and pharmacodynamic considerations. Anasthesiol Intensivmed Notfallmed Schmerzther. 2004;39(9):527-37.

37. Wilder-Smith OH. Opioid use in the elderly. Eur J Pain. 2005;9(2):137-40.

38. Hartikainen SA, Mäntyselkä PT, Louhivuori-Laako KA, Sulkava RO. Balancing pain and analgesic treatment in the home-dwelling elderly. Ann Pharmacother. 2005;39(1):11-6.

39. Pergolizzi J, Böger RH, Budd K, Dahan A, Erdine S, Hans G, et al. Opioids and the management of chronic severe pain in the elderly: consensus statement of an International Expert Panel with focus on the six clinically most often used World Health Organization Step III opioids (buprenorphine, fentanyl, hydromorphone, methadone, morphine, oxycodone) Pain Pract. 2008;8(4):287-313.

40. American Geriatrics Society Panel on Pharmacological Management of Persistent Pain in Older Persons. Pharmacological management of persistent pain in older persons. J Am Geriatr Soc. 2009;57(8):1331-46. 